\title{
The Possible Association of Hyperuricemia and/or Gout with Diabetes Mellitus*
}

\author{
By William M. Mikkelsen, M.D. \\ University of Michigan Medical School
}

Although the possibility of an association between gout and/or hyperuricemia and diabetes mellitus was first suggested in the late 18th century, the existence of such a relationship has yet to be conclusively established. The present report will review published data regarding the prevalence of gout and hyperuricemia in diabetic subjects, that of diabetes mellitus and impaired glucose tolerance in patients with gout, and will present pertinent data from the Tecumseh Community Health Study.

In Table 24 are presented results of studies of the prevalence of gout in diabetic subjects. The results are quite divergent, ranging from an estimate of one case of concomitant gout in 1,500 cases of diabetes mellitus ${ }^{8}$ to as high as eight or nine per cent..,5 Most recent reports can be summarized as suggesting that the prevalence of gout in subjects with diabetes mellitus is relatively low.

The occurrence of hyperuricemia in association with diabetes has also been reported. Several groups of investigators ${ }^{9,12}$ have reported the presence of hyperuricemia in patients in diabetic ketoacidosis, serum urate values reverting to normal as the ketosis diminishes. There are conflicting reports, however, regarding the prevalence of hyperuricemia in apparently controlled diabetics (Table 25). In a small group of 18 diabetic subjects de Candia ${ }^{11}$ found hyperuricemia in 50 per cent. In a larger group of 258 patients Padova and Bendersky $^{12}$ reported elevated serum urate values in approximately 25 per cent. In contrast to these reports Beckett and Lewis 9 found only 2.4 per cent of 800 diabetic subjects to be hyperuricemic. These authors also found the mean serum uric acid values for their diabetic subjects to be lower than those reported by others for nondiabetic subjects.

Surveys of the prevalence of diagnosed diabetes mellitus in gouty patients (Table 26) have yielded values ranging from three ${ }^{14}$ to as high as eight ${ }^{10}$ per cent. One authority, ${ }^{16}$ however, states that in his series of gouty patients this combination is rare, occurring in only three individuals. This latter ex-

\footnotetext{
*Dr. Mikkelsen's work was done in collaboration with H. J. Dodge, M.D., M.P.H.

From the Rackham Arthritis Research Unit and Department of Internal Medicine, Medical School, and the Department of Epidemiology, School of Public Health, The University of Michigan. The Rackham Arthritis Research Unit is supported by a grant from the Horace H. Rackham School of Graduate Studies.

Data from the Tecumseh Community Health Study is reported for the Research Staff of the Cardiovascular Research Center and the Tecumseh Community Health Study, supported under Program Project Grant H-6378, from the National Heart Institute, U. S. Public Health Service. The serum uric acid determinations were supported by Grant CD00005 from the U. S. Public Health Service.
} 
Table 24.-Prevalence of Gout in Diabetic Patients

\begin{tabular}{|c|c|}
\hline Authors & Prevalence of Gout \\
\hline Contani2 $^{2}(1877)$ & $0.5 \%$ \\
\hline Grube $^{3}(1895)$ & $9.0 \%$ \\
\hline Seckel$^{4}(1925)$ & $2.1 \%$ \\
\hline Van Noorden and Isaac ${ }^{5}$ (1927) & $8.0 \%$ \\
\hline Rabinowitch $^{6}$ (1928) & "4 times chance" \\
\hline Englehardt and Wagner ${ }^{7}(1950)$ & "Rare" \\
\hline Joslin, et als (1952) & "1 in 1500 ; rare" \\
\hline Beckett and Lewis ${ }^{9}(1960)$ & $0.8 \%$ \\
\hline Bendersky and Kreithen ${ }^{10}$ (1962) & $1.8 \%$ \\
\hline
\end{tabular}

Table 25.-Prevalence of Hyperuricemia in Diabetic Patients

\begin{tabular}{ccc}
\hline Authors & No. of Cases & $\begin{array}{c}\text { Prevalence of } \\
\text { Hyperuricemia }\end{array}$ \\
\hline deCandia $^{11}(1930)$ & 18 & $50.0 \%$ \\
Beckett and Lewis $^{9}(1960)$ & 800 & $2.4 \%$ \\
Padova and Bendersky $^{12}(1962)$ & 258 & $24.8 \%$ \\
\hline
\end{tabular}

Table 26.-Prevalence of Diabetes in Gouty Patients

\begin{tabular}{lcc}
\hline \multicolumn{1}{c}{ Authors } & No. of Cases & Prevalence of Diabetes \\
\hline Umber13 (1914) $^{13}$. & 278 & $5.4 \%$ \\
Kuzell, et al14 (1955) & 504 & $3.0 \%$ \\
Bartels, et al15 (1960) & 500 & $3.8 \%$ \\
Bendersky and Kreithen ${ }^{10}(1962)$ & & $8.0 \%$ \\
Talbott16 (1964) & & "Rare; only 3 cases \\
& & in his series" \\
\hline
\end{tabular}

perience is somewhat surprising since it suggests the possibility that gouty patients may actually have a lower prevalence of diabetes than the general population.

With this possibility in mind, the recent experience at The University of Michigan Hospital was reviewed (Table 27). Thus far in 1964, 21 new cases of primary gout have been encountered. In four instances glucose tolerance was not evaluated. In four a frankly diabetic glucose tolerance response was demonstrated. Of 12 cases in which only screening tests were performed, the results suggested "probable" diabetes (fasting blood sugar greater than $120 \mathrm{mg}$. per $100 \mathrm{ml}$. or 2 hour postprandial blood sugar greater than 180 mg. per $100 \mathrm{ml}$.) in five instances, "possible" diabetes ( 2 hour postprandial 140-179 mg. per $100 \mathrm{ml}$.) in two, and were normal in five cases. One subject, with a previous diagnosis of diabetes mellitus made elswhere, was found to have two normal fasting blood sugar values, but was not further evaluated. Thus, over 50 per cent of this small group of gouty patients was found to have impaired carbohydrate tolerance although none would have been recognized as diabetic without laboratory evaluation of glucose tolerance. This limited and uncontrolled experience does not warrant any firm conclusions, although it does suggest that carbohydrate tolerance is not uncommonly impaired in gouty subjects. 
Table 27.-New Cases of Primary Gout, 1964. The University of Michigan Hospital

$\begin{array}{ll}\text { Total: } 21 \text { patients } & \\ \text { Sex: Male, } 16 \quad \text { Female, } 5 & \\ \text { Age: } 20-72 \text { years; } 18 \text { age } 50 \text { or over } & \\ \text { Diabetic Status } & 4 \text { pts. } \\ \text { Diabetic Glucose Tolerance Test } & \\ \text { Screening tests only } & 5 \text { pts. } \\ \text { probable diabetes } & 2 \text { pts. } \\ \text { possible diabetes } & 5 \text { pts. } \\ \text { normal } & 1 \text { pt. } \\ \text { Previous clinical Dx, not confirmed } & 4 \text { pts. } \\ \text { Not studied } & \end{array}$

Table 28.-Prevalence of Abnormal Carbohydrate Tolerance in Gout

\begin{tabular}{|c|c|c|c|c|}
\hline Weiss, Segaloff and Moore ${ }^{17}$ & & 143 & & $28.0 \%$ \\
\hline$(1957)$ & controls & 143 & & $19.0 \%$ \\
\hline $\operatorname{Herman}^{18}(1958)$ & & 82 & "usual criteria" & $21.0 \%$ \\
\hline & & "more rigid criteria" & & $12.0 \%$ \\
\hline & controls & 27 & & $3.7 \%$ \\
\hline
\end{tabular}

Two studies have been reported in which the carbohydrate tolerance of gouty subjects has been assessed in comparison with that of nondiabetic controls (Table 28). Weiss, Segaloff and Moore ${ }^{17}$ demonstrated abnormal glucose tolerance in 28 per cent of 143 gouty subjects matched for age, sex and degree of obesity. Herman ${ }^{18}$ found impairment of glucose tolerance, using rigid diagnostic criteria, in 12 per cent of 82 gouty subjects as contrasted to 3.7 per cent of 27 "ambulant, nongouty, arthritic patients."

Data from the Tecumseh Community Health Study of 1959-1960,19,20 carried out under the direction of Drs. Thomas Francis, Jr. and Frederick H. Epstein, were examined for evidence of an association between gout or hyperuricemia and diabetes mellitus. The subjects of this study represent a natural population unselected for any disease process. Technically satisfactory serum uric acid determinations were made for 6,000 subjects, utilizing the enzymatic spectrophotometric method of Liddle, Seegmiller and Laster. ${ }^{21}$ This presentation is concerned with the 85 per cent of study subjects 20 years of age and over who had serum uric acid determinations.

In Table 29 are presented the age and sex specific correlation coefficients between observed serum uric acid and blood sugar, serum cholesterol and observed and relative weight. It will be seen that there is little evidence of association between serum uric acid, blood sugar and serum cholesterol, although there is some suggestion of association between serum uric acid and actual and relative weights.

The age and sex specific prevalence rates of diabetes mellitus, gout and coronary heart disease for study subjects 20 years of age and over for whom serum urate determinations were available are presented in Table 30 . The overall prevalence of diabetes was 1.9 per cent, of gout 0.6 per cent and of coronary heart disease 4.4 per cent in this group of 4,015 subjects. Since there is an appreciable variation of serum urate values with sex and age, ${ }^{22}$ 
Table 29.-Age and Sex Specific Correlation Coefficients Between Observed Serum Uric Acid and Blood Sugar, Serum Cholesterol, Observed Weight and Relative Weight

\begin{tabular}{crccc}
\hline \multirow{2}{*}{$\begin{array}{c}\text { Age Group } \\
\text { in Years }\end{array}$} & \multicolumn{4}{c}{ Correlation Coefficients (r) of Serum Uric Acid with: } \\
\cline { 2 - 5 } & Blood Sugar* & Serum Cholesterol & Observed Weight & Relative Weight \\
\hline & \multicolumn{5}{c}{ Males } & \\
$30-29$ & -0.046 & 0.087 & 0.144 & 0.195 \\
$40-49$ & 0.008 & 0.126 & 0.198 & 0.225 \\
$50-59$ & -0.054 & -0.027 & 0.217 & 0.230 \\
$60-69$ & -0.069 & 0.103 & 0.228 & 0.248 \\
$70-79$ & -0.018 & 0.133 & 0.290 & 0.314 \\
$20-79$ & 0.026 & 0.078 & 0.217 & 0.127 \\
Number of & -0.030 & 0.081 & 0.205 & 0.227 \\
subjects & 1185 & & & \\
& & 1909 & 1913 & 1906 \\
$20-29$ & -0.019 & Females & & \\
$30-39$ & 0.069 & 0.083 & 0.241 & 0.188 \\
$40-49$ & 0.061 & 0.042 & 0.340 & 0.314 \\
$50-59$ & 0.107 & 0.042 & 0.230 & 0.235 \\
$60-69$ & 0.059 & 0.034 & 0.270 & 0.251 \\
$70-79$ & -0.183 & -0.078 & 0.222 & 0.218 \\
\hline $20-79$ & 0.041 & 0.039 & 0.224 & 0.114 \\
Number of & & 0.041 & 0.270 & 0.243 \\
subjects & 1263 & & & \\
\hline
\end{tabular}

* Following a moditied glucose tolerance test in subjects who had eaten within 5 hours.

Computations prepared by Dr. Mark Kjelsberg and Mr. Jacob Keller.

individual serum urate values have been adjusted for this effect using the following formula:

\begin{tabular}{|c|c|c|c|}
\hline $\begin{array}{l}\text { Observed serum } \\
\text { urate conc. of the } \\
\text { individual subject }\end{array}$ & less & $\begin{array}{l}\text { Mean serum urate } \\
\text { conc. of his age- } \\
\text { sex-group }\end{array}$ & $+4.5 \mathrm{mg}$. per $100 \mathrm{ml}$ \\
\hline
\end{tabular}

This derived value, which corrects for age-sex differences in serum urate concentration, has been termed a "score" to differentiate it from the actual measured value. The "score," then, is a statistical device by means of which an individual's serum urate concentration can be evaluated, or correlated with other data, in comparison with other persons of the same age-sex group.

The mean serum urate scores of persons with diabetes mellitus, gout and coronary heart disease are indicated in Table 31. As would be expected, the highest value is observed in subjects with gout. Subjects with diabetes mellitus have a mean value lower than the grand mean for all subjects of 4.5 mg. per $100 \mathrm{ml}$., while subjects with coronary heart disease have an intermediate, somewhat elevated, mean value. Although these differences do 
Table 30.-Age and Sex Specific Prevalence (\%) of Coronary Heart Disease, Diabetes Mellitus and Gout in Persons 20 Years or Older for Whom Serum Uric Acid Scores Are Available

\begin{tabular}{|c|c|c|c|c|c|c|c|}
\hline \multirow[b]{3}{*}{$\begin{array}{l}\text { Age Group } \\
\text { in Years }\end{array}$} & \multirow[b]{3}{*}{$\begin{array}{c}\text { Number of } \\
\text { Subjects } \\
\text { with SUA } \\
\text { Scores }\end{array}$} & \multicolumn{6}{|c|}{ Subjects Diagnosed as Having: } \\
\hline & & \multicolumn{2}{|c|}{$\begin{array}{c}\text { Coronary Heart } \\
\text { Disease }\end{array}$} & \multicolumn{2}{|c|}{$\begin{array}{l}\text { Diabetes } \\
\text { Mellitus }\end{array}$} & \multicolumn{2}{|c|}{ Gout } \\
\hline & & Number & $\begin{array}{c}\% \text { of } \\
\text { Age } \\
\text { Group }\end{array}$ & Number & $\begin{array}{c}\% \text { of } \\
\text { Age } \\
\text { Group }\end{array}$ & Number & $\begin{array}{l}\% \text { of } \\
\text { Age } \\
\text { Group }\end{array}$ \\
\hline \multicolumn{8}{|c|}{ Males } \\
\hline $20-29$ & 391 & 3 & 0.8 & 0 & 一 & 1 & 0.3 \\
\hline $30-39$ & 581 & 5 & 0.9 & 3 & 0.5 & 3 & 0.5 \\
\hline $40-49$ & 407 & 15 & 3.7 & 5 & 1.2 & 3 & 0.7 \\
\hline $50-59$ & 283 & 33 & 11.6 & 6 & 2.1 & 6 & 2.1 \\
\hline $60-69$ & 166 & 31 & 18.7 & 9 & 5.4 & 0 & - \\
\hline 70 and over & 111 & 20 & 18.0 & 7 & 6.3 & 1 & 0.9 \\
\hline 20 and over & 1939 & 107 & 5.5 & 30 & 1.5 & 14 & 0.7 \\
\hline \multicolumn{8}{|c|}{ Females } \\
\hline $20-29$ & 495 & 1 & 0.2 & 1 & 0.2 & 2 & 0.4 \\
\hline $30-39$ & 590 & 1 & 0.2 & 3 & 0.5 & 2 & 0.3 \\
\hline $40-49$ & 414 & 6 & 1.4 & 6 & 1.4 & 2 & 0.5 \\
\hline $50-59$ & 281 & 18 & 6.4 & 10 & 3.6 & 3 & 1.1 \\
\hline $60-69$ & 163 & 25 & 15.3 & 11 & 6.7 & 0 & - \\
\hline 70 and over & 133 & 20 & 15.0 & 14 & 10.5 & 1 & 0.8 \\
\hline 20 and over & 2076 & 71 & 3.4 & 45 & 2.2 & 10 & 0.5 \\
\hline
\end{tabular}

Table 31.-Comparison of Mean Serum Uric Acid Scores of Persons with Coronary Heart Disease (CHD), Diabetes Mellitus and Gout

\begin{tabular}{|c|c|c|c|}
\hline \multirow[b]{2}{*}{ Disease Classification } & \multirow[b]{2}{*}{$\begin{array}{l}\text { Number of } \\
\text { Subjeets }\end{array}$} & \multicolumn{2}{|c|}{$\begin{array}{c}\text { SUA Scores } \\
\text { (mg. per } 100 \mathrm{ml} \text { ) }\end{array}$} \\
\hline & & Mean & $\begin{array}{c}\text { Standard } \\
\text { Deviation }\end{array}$ \\
\hline \multicolumn{4}{|c|}{ Without Regard to Combinations } \\
\hline Coronary heart disease & 178 & 4.72 & 1.123 \\
\hline Diabetes mellitus & 75 & 4.37 & 1.136 \\
\hline Gout & 24 & 5.61 & 1.574 \\
\hline \multicolumn{4}{|c|}{ Subjects Having a Single Disease } \\
\hline Coronary heart disease & 162 & 4.74 & 1.118 \\
\hline Diabetes & 63 & 4.41 & 1.163 \\
\hline Gout & 20 & 5.60 & 1.671 \\
\hline \multicolumn{4}{|c|}{ Subjects Having Two Diseases } \\
\hline CHD and diabetes & 12 & 4.17 & 0.996 \\
\hline CHD and gout & 4 & 5.62 & 1.145 \\
\hline
\end{tabular}

not appear great, they are significant at the five per cent level at least by the " $\mathrm{t}$ " test. The mean scores, and the statistical significance of the differences at the five per cent level, are essentially unchanged when subjects having multiple diagnoses are excluded. Finally, it will be observed that whereas twelve subjects had diabetes mellitus plus coronary heart disease and 
four gout plus coronary heart disease, there were none with a diagnosis of both gout and diabetes mellitus.

Presently available information does not suggest an increased prevalence of clinical gout in patients with diabetes mellitus. Although diabetic ketoacidosis may often be associated with temporary hyperuricemia, it is as yet uncertain how prevalent hyperuricemia is in subjects with well controlled or moderately controlled diabetes. The evidence suggests on the one hand that hyperuricemia may be present in 25 per cent or more of such subjects, and on the other that their mean serum urate values may be lower than normal. Reports of an apparently increased prevalence of hyperuricemia in diabetics should be examined critically in view of the many variables influencing measurement of serum urate content, and of the difficulties in arriving at a satisfactory definition of hyperuricemia. There is a need for further studies in which serum urate values of diabetic and nondiabetic subjects are compared under controlled conditions.

The weight of available evidence would suggest that diabetes mellitus is not a rare disease in patients with the diagnosis of gout, although it does not necessarily establish that it is higher than in nongouty subjects. When the two disorders coexist the diabetes is almost always of the mild, "maturity onset" variety. It is asymptomatic or latent, but capable of detection by presently accepted laboratory measurements of carbohydrate tolerance. Although the two controlled studies of carbohydrate tolerance in gouty patients agree in suggesting an increased frequency of abnormality in subjects with gout, a word of caution is appropriate. Recent evidence from the National Health Survey ${ }^{23}$ indicates that the blood glucose levels after challenge with an oral glucose load increase with age. It is by no means certain that the diagnostic criteria accepted for healthy young adults are applicable to subjects over age 40 or 50 . Since gout is encountered most frequently in the middle and later years of life, this is an important consideration. Further studies of carbohydrate tolerance in gouty and nongouty subjects carefully matched for age and sex (and, if possible, other factors such as obesity, etc.) are clearly indicated.

Thus far, analysis of data from the Tecumseh Community Health Study has failed to establish the presence of an association of serum urate concentration and blood sugar levels. Subjects with diabetes mellitus were found to have lower mean serum urate values than others in their age-sex groups. No subjects were identified in whom both gout and diabetes mellitus existed. Although essentially negative, these results, based on a single examination of these subjects, do not rule out the possibility of such an association.

\section{REFERENCES}

1. Whytt, R.: The Works of Robert Whytt, Edinburgh, Beckett, p. 707, 1768.

2. Cantani: Der Diabetes Mellitus, Berlin, 1877.

3. Grube, K.: Zur Aetiologie des Sogen- nannten Diabetes Mellitus, Ztschr. f. klin. Med. 27:465, 1895.

4. Seckel, H.: Beobachtungen über Heredofamiliäre und Konstitutionelle Häufung von Stoffwechselleiden beim Diabetes Mellitus. Ztschr. f. klin. 
Med. 102:195, 1925.

5. van Noorden, C. H., and Isaac, C.: Dic Zuckerkrankheit und ihre Behandlung, Sth ed., Berlin, J. Springer, 1927.

6. Rabinowitch, I. M.: Unusual Case of Diabetes and Gout. Canad. Med. Ass. J. 19:682, 1928.

7. Englehardt, H. T., and Wagner, E. L.: Gout, Diabetes Mellitus and Obesity, a Poorly Appreciated Syndrome. Southern Med. J. 43:51, 1950.

8. Joslin, E. P., Root, H. F., White, P., and Marble, A.: The Treatment of Diabetes Mellitus, 9th ed., Philadelphia, Lea and Febiger, p. 93, 1952.

9. Beckett, A. G., and Lewis, J. G.: Gout and the Serum Uric Acid in Diabetes Mellitus. Quart. J. Med. 29:443, 1960.

10. Bendersky, G., and Kreithen, H.: Unpublished Data, quoted by Padova, J., and Bendersky, G.: Hyperuricemia in Diabetic Ketoacidosis. New Eng. J. Med. 267:550, 1962.

11. de Candia, S.: L'acido Urico Ematico nel Diabete Mellito. Riforma Med. 46:1035, 1930.

12. Padova, J., and Bendersky, G.: Hyperuricemia in Diabetic Ketoacidosis. New Eng. J. Med. 267:550, 1962.

13. Umber, F.: Ernährung und Stoffwechselkrankheiten, 2nd ed., Berlin, Urban and Schwarzenberg, 1914.

14. Kuzell, W. C., Schaffarzick, R. W., Naugler, W. E., Koets, P., Mankle, E. A., Brown, B., and Champlin,
B.: Some Observations on 520 Gouty Patients. J. Chron. Dis. 2:645, 1955.

15. Bartels, E. C., Balodimos, M. C., and Corn, L. R.: The Association of Gout and Diabetes Mellitus. Med. Clin. No. Am. 44:443, 1960.

16. Talbott, J. H.: Gout, 2nd ed., New York and London, Grune and Stratton, p. 145, 1964.

17. Weiss, T. E., Segaloff, A., and Moore, C.: Gout and Diabetes. Metabolism 6:103, 1957.

18. Herman, J. B.: Gout and Diabetes, Metabolism 7:703, 1958.

19. Epstein, F. H.: An Epidemiological Study in a Total Community, Univ. of Mich. Med. Bull. 26:307, 1960.

20. Francis, T., Jr.: Aspects of the Tecumseh Study. Pub. Health Reps. 76: 963, 1961.

21. Liddle, L., Seegmiller, J. E., and Laster, L.: The Enzymatic Spectrophotometric Method for Determination of Uric Acid. J. Lab. and Clin. Med. 54:903, 1959.

22. Mikkelsen, W. M., Dodge, H. J., and Valksenburg, H.: The Distribution of Serum Uric Acid Values in a Population Unselected as to Gout or Hyperuricemia, Tecumseh, Michigan, 1959-1960, Am. J. Med. 39:242, 1965.

23. U. S. National Health Survey: Glucose Tolerance of Adults, United States, 1960-1962, Vital and Health Statistics, PHS Pub. No. 1000, Series 11, No. 2, Public Health Service, Washington, D. C., May, 1964.

\section{Discussion}

DR. BARTELS: We reported our studies of gouty patients with diabetes in March, 1960, because Dr. Joslin had previously reported that the combination of gout and diabetes mellitus was extremely rare.

In a survey of 900 patients with gout, we found 29 patients had diabetes mellitus also. In most patients the diabetes developed after the gout. The two conditions developed simultaneously in only one patient, and in two cases diabetes developed after the patients had had gout for 5 and 17 years, respectively. Diabetes was found in 3.8 per cent of all patients with gout-a higher percentage than the 1.3 per cent incidence found in the average population.

Recently, a new group of patients with gout was reviewed in which 27 cases of diabetes mellitus were found, making the total number of patients with gout and diabetes observed to date 56 . 
An early clinical observation thought significant was that patients with recurring gout had no further gout attacks if diabetes developed. One patient had no further attacks for 15 years. Three patients who were observed for five years had no further attacks of gout. This observation led us to the possible conclusion that diabetes has an ameliorating effect on gout. In reviewing our figures in detail, 15 of the cases studied seem to support this conclusion. We realize that gout might take on a different pattern at different times, but in most of these patients the gout patterns were already well established.

A total of 900 gouty patients was studied and 56 patients were found to have both gout and diabetes. These clinical observations were reported in the hope that others would test this clinical impression. We found the association between the two diseases to be fairly common, in contrast to Dr. Joslin's findings which indicated a rare association of the two diseases.

Dr. Maclachlan: The first five gouty patients to be admitted to our Clinical Research Unit for studies previously described had abnormal glucose tolerance tests. In order to determine the frequency of this finding, 29 of our gouty patients who were being followed in the Rheumatism Clinic were given an oral tolerance test using $100 \mathrm{Gm}$. of glucose. No attempt was made to control the diets of these patients prior to the test and I have no information regarding the carbohydrate content of the diets. 25 of the 29 patients showed an abnormal response. This was characterized in almost all these cases by an elevated two hour value of $120 \mathrm{mg}$. per cent or higher, although the fasting level was usually normal. Only one of these patients was believed to have diabetes and was receiving tolbutamide.

The control group, chosen randomly and matched by sex, age, and weight, was selected from patients who were attending general medical clinic. Although the study is still in progress, the results in 54 patients indicate an abnormal response to an oral glucose load in 40 per cent of these individuals. This percentage does seem to be quite high, but recently it has been pointed out that a decrease in carbohydrate tolerance, particularly in the older age group, is more common than we have thought.

Many of our gouty patients were taking probenecid at the time the glucose tolerance test was carried out, but there were also a good many patients with abnormal responses to the test who were not receiving any drug.

Dr. Robinson: Dr. Maclachlan, were your patients given a test dose of glucose or was this two hours after a high carbohydrate meal?

Dr. Maclachlan: They were given a $100 \mathrm{Gm}$. glucose load after an overnight fast. Blood samples were taken in the fasting state and one half hour, one, two, and three hours after the test dose of glucose.

Dr. Robinson: Did you also want to comment with respect to serum triglyceride levels in your gouty patients?

Dr. Maclachlan: At the time the glucose tolerance tests were performed, fasting blood samples were taken for measurement of serum triglyceride levels. It was noted that the mean value for triglyceride was lower in the control group of patients in general medical clinic than it was in the gouty 
patients. The mean values were $116 \mathrm{mg}$. per cent in the 54 control patients and $144 \mathrm{mg}$. per cent in the 23 gouty patients.

Dr. WAllace: Dr. Feldman's and my results ${ }^{1 *}$ are remarkably similar to those of Dr. Maclachlan. We were interested in the interrelationships between gout and lipid abnormalities. We chose to select our patients with gout for the absence, as far as we could judge it clinically, of objective evidence of arteriosclerotic disease. These patients with gout, then, had no evidence of hypertension, coronary, cerebral or peripheral vascular disease, diabetes mellitus, or a wide variety of other conditions that imply arteriosclerotic disease. Our controls were primarily husbands of clinic and hospitalized patients and were healthy; the only selection was for the absence of arteriosclerotic disease and to match the age range of the gouty patients.

The only significant difference between the gout and the control groups was in serum triglyceride. The mean serum triglyceride in the patients with gout was $142 \mathrm{mg}$. per $100 \mathrm{ml}$; the mean for the healthy men was $100 \mathrm{mg}$. per $100 \mathrm{ml}$. This difference was significant $(\mathrm{p}<0.01)$. The frequency of elevated triglycerides was also much greater in the group of patients with gout than in the control group. Cholesterol and other lipid moieties studied did not differ significantly in the two groups.

Dr. Robinson: How large a number did you have in each group approximately, Dr. Wallace?

Dr. Wallace: 34 gouty patients and 28 controls.

Dr. Decker: I don't think Dr. Maclachlan gave the number of gouty patients who showed elevated two hour glucose levels.

Dr. Maclachlan: There were 29 gouty patients and in 25 of these abnormal glucose levels were found.

Dr. Decker: In response to a glucose tolerance test?

Dr. Maclachlan: Yes.

Dr. WALLACE: I must say that in our group we did not study this so their normal carbohydrate was defined as a normal fasting blood sugar not as a glucose tolerance test.

Dr. Maclachlan: That is interesting because in many of our patients with gout the fasting blood glucose level was normal.

Dr. Decker: Were they receiving medication?

Dr. Machlachlan: Yes, many of them were receiving probenecid and colchicine.

Dr. Wallace: None of our patients were on any medication.

Dr. Decker: Salicylates?

Dr. Machlachlan: No.

Dr. Hall: I want to make a few remarks about diabetes. Our findings are essentially the same as Dr. Mikkelsen's. The mean serum uric acid level in 110 diabetics was the same as in the population at risk and the mean post meal blood sugar was the same in the gouty patients as it was in the population at risk.

\footnotetext{
*Feldman, E. and Wallace, S.: Hypertriglyceridemia in Gout, Circulation 29:508, 1964.
} 
I think that one has to be very careful, especially in dealing with percentages and a small number of patients, to test for significance. The report, for example, by Weiss et al, is not significant and looking at the one by Herman it appears to me that that would not be a significant statistical difference either. I think that all we can say is that our findings, which were based not on glucose tolerance tests but were post meal blood sugars, did not show any assocation.

None of our gouty patients had diabetes. There were 4 hyperuricemics in 110 diabetics, over $7.0 \mathrm{mg}$. per cent serum uric acid level, that is.

Dr. Decker: Could Dr. Mikkelsen give us the mean SUA scores for the entire population from which Table 31 is drawn. Maybe I've missed that.

Dr. Mikkelsen: It was 4.5. The score, as I said previously, is an attempt to correct the individual serum uric acid value for the age and sex variations that seem to be present in the Tecumseh population. It is a statistician's device. Essentially what it does is to attempt to consider serum uric acid value for each individual in comparison with other individuals of the same age and sex group. I think in general it is apparent that our data are very much like Dr. Hall's in that in adults the levels don't vary greatly, except in females at an age period that would seem to correspond with the menopause. There are very significant changes in children, but that's not pertinent in this group.

Dr. Robinson: What is your normal for fasting blood sugar, Dr. Maclachlan?

Dr. Maclachlan: $100 \mathrm{mg}$. per cent.

DR. Robinson: What would you say the average fasting blood sugar was in your group of patients?

Dr. MACLACHLAN: 90-95 mg. per cent.

Dr. Seegmiller: I'd like to ask Dr. Bartels if his patients with gouty arthritis and diabetes were in an older age group than the nondiabetic subjects with gouty arthritis.

Dr. Bartels: A study of that kind was not done.

Dr. Robinson: Further questions?

Dr. Gutman: Dr. Bartels, is your group of gouty patients under treatment with uricosuric agents eating a lot more than they used to before they were being treated in this way?

Dr. Bartels: I can only say that most of them are overweight. For instance, all of the last group that we have studied-this new 27 that we have since 1960-all of these patients are overweight. That's the only thing I can answer about that.

Dr. Gutman: The reason I ask is, ever since the uricosuric agents came in, the diet in our own group has been I think unduly liberalized, so when you compare your group after 1955, let's say, your 1960 group with a group before the introduction of uricosuric drugs there may appear to be a large increase in the number of diabetic subjects encountered recently.

DR. Y $\ddot{U}$ : What is the incidence of a family history of diabetes in those who developed manifest diabetes.

Dr. BARTELS: I'm sorry I can't give you those figures. 
Dr. Robinson: One might express the feeling that in studies of this type, if we take any particular point in time we may not obtain a complete or accurate picture. These are diseases that take time to develop. Observations of patient groups, or population groups, over a period of time will be necessary in order to get some idea of the possible correlations.

Before we terminate the discussion, we might mention the problem of hyperuricemia in relation to psoriasis and the relationship of sarcoidosis to hyperuricemia.

Dr. SEegmillen: There is no unanimity of opinion regarding the exact incidence of hyperuricemia in psoriasis. Dr. Eisen became interested in this at the National Institutes of Health and we did some studies of the incorporation of glycine-C14 into urinary uric acid in a group of patients who have psoriasis. The major finding was a maximal incorporation of isotope into urinary uric acid around the 3rd to 4th day, in contrast to the peak on the lst or 2 nd day found in patients with primary gout, or on the 12th to 15 th day as observed in patients with secondary gout associated with myloproliferative diseases. We thought the maximum incorporation on the $3 \mathrm{rd}$ to 4th day reflected the increased proliferation of the epidermis involved in formation of psoriatic scales.

We did a study on one woman who showed overincorporation of glycine into uric acid at a time when she was suffering from an exacerbation of her psoriasis. This returned to the normal range and pattern when she was studied during a remission from her psoriasis. We did one study in a patient who had both gout and psoriasis and in this situation the pattern of incorporation was more that of primary gout than of psoriasis. Perhaps psoriasis is one more condition that can contribute to an increase in uric acid production.

Dr. Robinson: Were the patients in whom these incorporation studies were carried out hyperuricemic?

Dr. SeEgmiller: Yes, moderately hyperuricemic except for the study on the woman after remission whose serum urate had returned to the normal range.

Dr. Robinson: What has been your experience in managing patients with gout who happen to have psoriasis?

Dr. Seegmilier: The patients with gout and psoriasis that we have had occasion to treat happen to have had fairly mild psoriasis which has responded well to topical ointments. The gout responded as would be expected to uricosuric drugs and colchicine. The patients with more severe psoriasis and psoriatic arthritis studied by Dr. Bunim's group responded to methotrexate therapy but they still regard this as strictly an experimental approach to study of the disease rather than a recommended form of therapy.

Dr. Sorensen: I may mention also a case we had of primary gout and psoriatic arthritis in the same patient, who also had a strongly positive serological reaction for rheumatoid arthritis. Now, apparently this patient had a typical incorporation peak-your patient had two of primary incorporation. $\mathrm{He}$ is now entirely free of skin symptoms but still excretes a tremendous amount of uric acid in the urine, so I think this is quite clearly primary gout. 
The most interesting thing is that he had gone to a dermatologist for approximately 25 years and had extensive lesions, nearly all over his body, but since his uric acid in the plasma fell to the normal range, he has been free of psoriasis. He's not receiving any local treatment to the skin.

Dr. McCarty: I have another case of psoriatic arthritis and gout and it is remarkable. He is a physician, so we have a very good history of his attacks and other symptoms. He has two distinct histories; one is chronic, with occasional remissions and exacerbations, but the fluid retained in the joints, even though he was hyperuricemic at the time, had no crystals in it; this chronic form does not respond to phenylbutazone or colchicine. Superimposed on this he has acute attacks and has crystals with the acute attacks and these are responsive to colchicine.

Dr. WYNGaARden: We see quite a lot of sarcoid at Duke and have never systematically analyzed these patients, but just on informal statistics kept on the ward, I'd say roughly one-fourth of these patients have a serum uric acid of $7.0 \mathrm{mg}$. per cent or above. This is by the clinical chemistry method, which agrees within $0.2 \mathrm{mg}$. per cent with our enzymatic method. We have looked at a few of the 24 hour excretions of uric acid in these patients and they've always been within normal limits. We've never done any clearance studies on them or any isotope studies.

A few of these patients have been given chlorothiazide for one reason or another, and the serum uric acid rose still higher. We have then seen attacks which were clearly gouty, and colchicine responsive. As you know, the patient with sarcoidosis is also prone to other types of joint attacks, both acute and chronic, and these are frequently difficult to diagnose, especially the more acute ones. I think now that we have the opportunity of looking at the joint fluid more systematically we should be able to solve these problems. We have sometimes treated such attacks with colchicine with a feeling that they responded. There is also Dr. Kaplan's report of partial responses to colchicine and others who claim partial responses.

Dr. Rodnan: Has anyone found crystals in the joint fluid from sarcoid arthritis?

Dr. McCarty: This has not been reported, to my knowledge. 